\title{
Helminth parasites of the lesser great cormorant Phalacrocorax carbo sinensis from two nesting regions in the Czech Republic
}

\author{
František Moravec and Tomáš Scholz
}

Institute of Parasitology, Biology Centre of the Czech Academy of Sciences, České Budějovice, Czech Republic

\begin{abstract}
Parasitological examinations of 102 specimens of the lesser great cormorant Phalacrocorax carbo sinensis (Blumenbach) from two nesting regions in the Czech Republic (South Bohemia and South Moravia) were carried out at the Institute of Parasitology, Czech Academy of Sciences (previously the Czechoslovak Academy of Sciences) in the years 1987-1992. In them, a total of 19 species of helminth parasites was found, including Trematoda (11 species), Cestoda (2), Nematoda (4) and Acanthocephala (2), which can be divided into three main groups regarding their host specificity: parasites specific for cormorants (Phalacrocorax spp.) (37\%), those parasitic mainly in cormorants (16\%) and non-specific parasites (47\%). Of the 19 species recorded, 100\% were found in South Moravia, but only $47 \%$ of these 19 species in South Bohemia. The higher number of helminth species in cormorants from South Moravia and a higher proportion of non-specific species may be associated with the presence of the large Nové Mlýny water reservoir, in addition to better ecological and environmental conditions in this warmer region. Scanning electron microscopical examination of three common nematode species parasitising cormorants, Contracaecum rudolphii Hartwich, 1964, Desmidocercella incognita Solonitsin, 1932 and Syncuaria squamata (von Linstow, 1883), revealed some taxonomically important, previously unreported morphological features, such as the cephalic structures, numbers and distribution of male caudal papillae or the shapes of spicules.
\end{abstract}

Keywords: Phalacrocoracidae, fish-eating birds, helminth fauna, morphology, ecology, Central Europe

The great cormorant Phalacrocorax carbo (Linnaeus) (Pelecaniformes: Phalacrocoracidae) is a migratory fish-eating bird nesting in colonies. Its area of distribution is very extensive, including all continents except for South America and Antarctica. The type subspecies $P$. carbo car$b o$ (Linnaeus) is found mainly in Atlantic waters and nearby inland areas, e.g. on western European coasts, whereas the subspecies $P$. carbo sinensis (Blumenbach) is distributed from northern and central Europe to southern China (Nelson 2005). According to Hudec and Černý (1972), all great cormorants occurring in the Czech Republic belong to $P$. carbo sinensis. However, the validity of this subspecies has recently been questioned by Kennedy and Spencer (2014)

Whereas the European population of $P$. carbo sinensis was almost extinct in the half of the 20th century, its expansive increase began due to protective measures adopted in different European countries in 1965-1981. In former Czechoslovakia, the only large nesting colony of great cormorants was that near the vilage of Biskupice on the Danube River, southern Slovakia, which existed from about 1920 to 1967 (Áč 1983). Although in the past there were several unsuccessful attempts of great cormorants to nest in the territory of the present Czech Republic, their first permanent colony appeared in South Moravia only in 1982 (Macháček 1983). In South Bohemia, the first cormorant colonies appeared during 1985-1989. In 2010, there were six cormorant colonies in the Czech Republic with only about 350 nesting pairs as a result of the measures to regulate cormorant populations (Polák 2010).

Because of a very negative impact of the presence of cormorants for fisheries in South Bohemia and South Moravia (western and eastern parts of the Czech Republic, respectively) with intensive fish culture, investigations into the helminth parasites of the lesser great cormorant $P$. carbo sinensis in these two main nesting regions were carried out by the research team of the Institute of Parasitology, then the Czechoslovak Academy of Sciences, in České Budějovice during 1987-1992. The purpose of this work was mainly to recognise and evaluate the helminth fauna of great cormorants in the two ecologically different regions and to indicate a possible importance of cormorants' parasites for the health condition of cultured fish. Some partial results of these studies, mainly those on trematodes and acanthocephalans, were already reported in the papers of Moravec et al. (1988, 1994), Moravec (1990, 2009), Scholz et al. (1992), Našincová et al. (1993a,b, 1994) and Moravec and Scholz (1994), but the general evaluation of

Address for correspondence: F. Moravec, Institute of Parasitology, Biology Centre of the Czech Academy of Sciences, Branišovská 31 , 370 05 České Budějovice, Czech Republic. Phone +420 38777 5432; Fax: +420 38 5310388; E-mail: moravec@paru.cas.cz 
Table 1. List of the localities from where cormorants, Phalacrocorax carbo sinensis (Blumenbach), were examined.

\begin{tabular}{llcl}
\hline No. & Locality & No. of cormorants examined & Year(s) and month(s) \\
\hline & South Bohemia (Jindřichův Hradec district) & & \\
\hline 1 & Pond Staré Jezero near Třeboň & 2 & 1987: XI \\
2 & Pond Ženich near Třeboň & 33 & $1989,1990,1991$, 1992: V, VI, VII, VIII \\
3 & Pond Nový Vdovec near Stará Hlína & 11 & $1990:$ V, VII \\
\hline & South Moravia (Pohořelice district) & & \\
\hline 4 & Pond Starý near Pohořelice & 2 & 1989: IX \\
5 & Pohořelice & 6 & 1991: VII \\
6 & Nové Mlýny water reservoir & 33 & 1991, 1992: IV, V \\
7 & Jaroslavice & 9 & 1991: VII \\
8 & Pond Prostřední near Lednice & 6 & 1989: IX \\
\hline
\end{tabular}

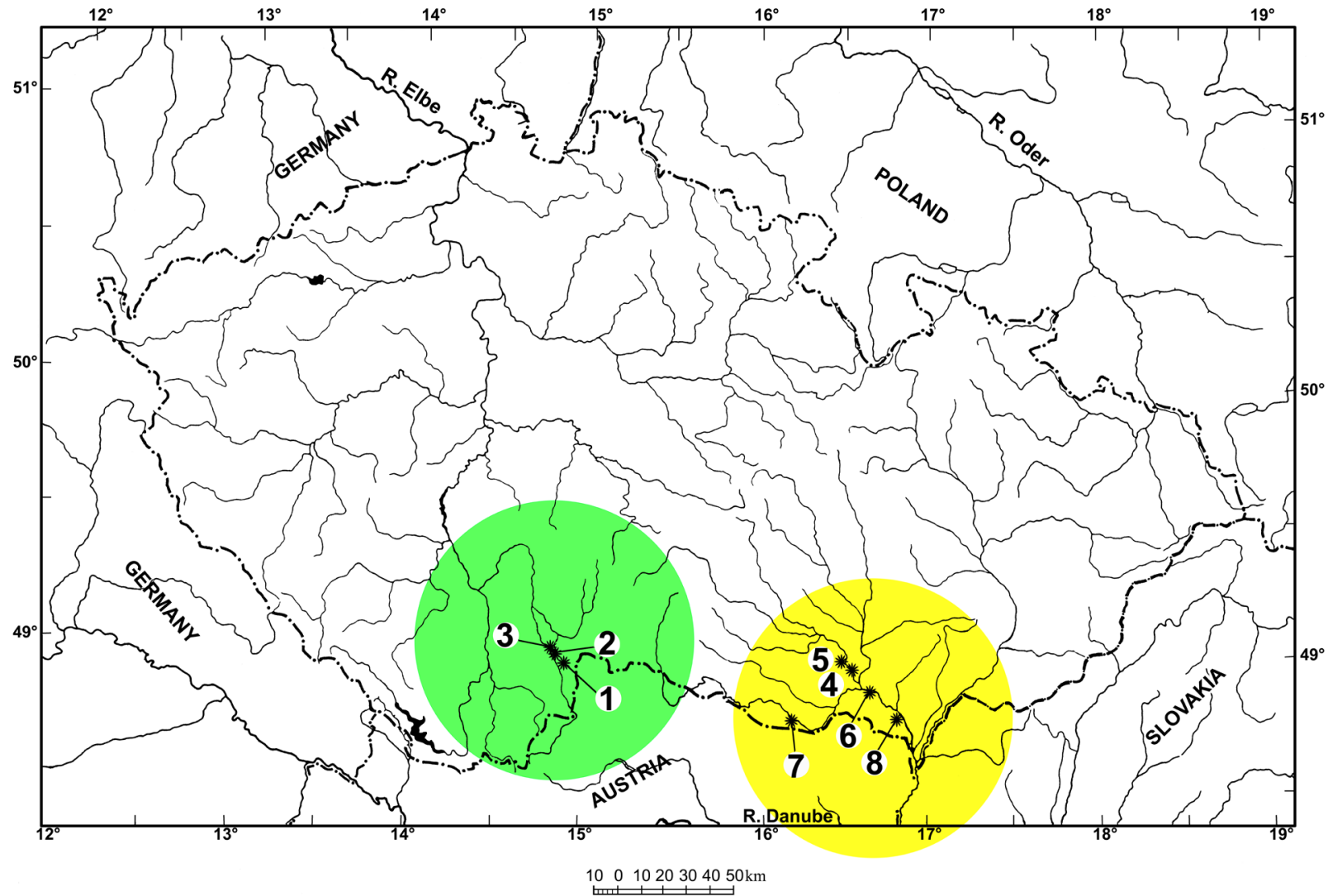

Fig. 1. Map showing sampling sites in the Czech Republic from where the cormorants were obtained (numbers designate the localities listed in Table 1). Regions of South Bohemian and South Moravian localities roughly marked in green and yellow, respectively.

the cormorants' helminth fauna, as well as more detailed data on cestodes and nematodes, remained unpublished and are presented only herein.

\section{MATERIALS AND METHODS}

A total of 102 specimens of lesser great cormorants Phalacrocorax carbo sinensis, including adults and several chicks, was examined from South Bohemian and South Moravian localities during 1987-1992 (see Table 1 and Fig. 1). The freshly shot birds and a few killed chicks previously collected from nests were examined for the presence of helminth parasites using the method of a complete helminthological dissection.

The parasites obtained were treated by usual helminthological methods, i.e. they were fixed in $4 \%$ formalin and then, for light microscopical (LM) examination, the trematodes, cestodes and partly acanthocephalans were mostly stained in carmine and mounted as permanent slides in Canada balsam, whereas the nematodes were cleared with glycerine as temporal preparations. After microscopical examination, these materials were mostly deposited in the Helminthological Collection of the Institute of Parasitology, Biology Centre of the Czech Academy of Sciences, in České Budějovice (http://www.paru.cas.cz/en/collections).

Some nematode and acanthocephalan specimens intended for the scanning electron microscopical (SEM) examination were postfixed in $1 \%$ osmium tetroxide (in phosphate buffer), dehydrated through a graded ethanol series and amylacetate, critical-point-dried and sputter-coated with gold; they were examined using a Tesla BS-300 scanning electron microscope at an accelerating voltage of $15 \mathrm{kV}$. Species of helminth parasites are listed alphabetically in each of the higher taxonomic groups. 
Table 2. Quantitative data on the occurrence of helminth parasites of Phalacrocorax carbo sinensis (Blumenbach) in South Bohemian and South Moravian localities: total prevalence (number of hosts infected/examined), range of intensity and mean intensity (in parentheses).

\begin{tabular}{|c|c|c|c|}
\hline Parasite species & Group No.* & South Bohemia $(\mathrm{n}=46)$ & South Moravia $(\mathrm{n}=56)$ \\
\hline \multicolumn{4}{|l|}{ Trematoda } \\
\hline Apophallus muehlingi (Jägerskiöld, 1899) & 3 & - & $5 \%(3 / 56) ; 1-13(9)$ \\
\hline Ascocotyle longa Ransom, 1920 & 3 & - & $2 \%(1 / 56) ; 10(10)$ \\
\hline Cercarioides aharonii Witenberg, 1929 & 3 & - & $2 \%(1 / 56) ; 1(1)$ \\
\hline Galactosomum lacteum (Jägerskiöld, 1896) & 3 & - & $2 \%(1 / 56) ; 15(15)$ \\
\hline Heterophyes aequalis Looss, 1902 & 3 & - & $2 \%(1 / 56) ; 680(680)$ \\
\hline Holostephanus dubinini Vojtek et Votková, 1968 & 1 & - & $16 \%(9 / 56) ; 1-37(8)$ \\
\hline Hysteromorpha triloba (Rudolphi, 1819) & 2 & $13 \%(6 / 46) ; 1-16(4)$ & $38 \%(21 / 56) ; 1-70(17)$ \\
\hline Metorchis xanthosomus (Creplin, 1846) & 3 & $4 \%(2 / 46) ; 1-2(2)$ & $11 \%(6 / 56) ; 1-9(3)$ \\
\hline Paryphostomum radiatum (Dujardin, 1845) & 1 & $11 \%(5 / 46) ; 1-8(4)$ & $45 \%(25 / 56) ; 1-210(40)$ \\
\hline Petasiger exaeretus Dietz, 1909 & 1 & $17 \%(8 / 46) ; 1-47(7)$ & $21 \%(12 / 56) ; 1-535(48)$ \\
\hline Petasiger phalacrocoracis (Yamaguti, 1939) & 1 & $11 \%(5 / 46) ; 1-162(78)$ & $61 \%(34 / 56) ; 2-1816(295)$ \\
\hline \multicolumn{4}{|l|}{ Cestoda } \\
\hline Ligula intestinalis (Linnaeus, 1758) & 3 & - & $2 \%(1 / 56) ; 3(3)$ \\
\hline Paradilepis scolecina (Rudolphi, 1819) & 2 & $48 \%(22 / 46) ; 1-780(97)$ & $43 \%(24 / 56) ; 1-858(210)$ \\
\hline \multicolumn{4}{|l|}{ Nematoda } \\
\hline Baruscapillaria rudolphii Moravec, Scholz et Našincová, 1994 & 1 & - & $4 \%(2 / 56) ; 2(2)$ \\
\hline Contracaecum rudolphii Hartwich, 1964 & 2 & $65 \%(30 / 46) ; 1-41(5)$ & $73 \%(41 / 56) ; 1-735(88)$ \\
\hline Desmidocercella incognita Solonitsin, 1932 & 3 & $30 \%(14 / 46) ; 1-218(35)$ & $20 \%(11 / 56) ; 2-23(9)$ \\
\hline Syncuaria squamata (von Linstow, 1883) & 1 & $15 \%(7 / 46) ; 1-12(4)$ & $20 \%(11 / 56) ; 1-4(2)$ \\
\hline \multicolumn{4}{|l|}{ Acanthocephala } \\
\hline Andracantha phalacrocoracis (Yamaguti, 1939) & 1 & - & $2 \%(1 / 56) ; 7(7)$ \\
\hline Southwellina hispida (Van Cleave, 1925) & 3 & - & $2 \%(1 / 56) ; 42(42)$ \\
\hline
\end{tabular}

* 1 - strictly specific-species for which cormorants (Phalacrocorax spp.) serve as the only definitive hosts; 2 - species parasitising mainly cormorants, but may occasionally occur in water birds belonging to other families; 3 - non-specific species parasitising mostly aquatic birds of different families or even mammals.

\section{RESULTS}

\section{Survey of helminth parasites recorded from Phalacrocorax carbo sinensis within this study during the period of 1987-1992}

A total of 19 species of helminths was found in cormorants (Table 2):

\section{Trematoda}

The trematodes of this material have already been dealt with in more detail by Našincová et al. (1993a, 1994).

\section{Apophallus muehlingi (Jägerskiöld, 1899)}

This trematode was found in the small intestine of cormorants in the Nové Mlýny water reservoir in South Moravia (April 1991: prevalence 8\% [1 cormorant infected/13 cormorants examined], intensity of infection 13; May 1992: 2/6, 1-13 [mean intensity 7]).

\section{Ascocotyle (Phagicola) longa Ransom, 1920}

Specimens of this species were found only once in the small intestine of a cormorant from the Nové Mlýny water reservoir (April 1992: 7\% [1/14], 10) in South Moravia.

\section{Cercarioides aharonii Witenberg, 1929}

A single specimen of this species was found in the cloaca of one cormorant in the Nové Mlýny water reservoir in South Moravia (April 1992: 7\% [1/14], 1).
Galactosomum lacteum (Jägerskiöld, 1896)

Specimens of this species were found only once in the small intestine of a cormorant from the Nové Mlýny water reservoir in South Moravia (April 1992: 7\% [1/14], $15)$.

\section{Heterophyes aequalis Looss, 1902}

Very many specimens were recorded from the small intestine of a cormorant in the Nové Mlýny water reservoir in South Moravia (April 1992: 7\% [1/14], 680).

\section{Holostephanus dubinini Vojtek et Votková, 1968}

This species was found in the intestine of cormorants from two South Moravian localities: Pohořelice (July 1991: 1/6, 4) and Nové Mlýny water reservoir (April 1992: 43\% [6/14], 1-16 [5]; May 1992: 2/6, 3-37 [20]).

\section{Hysteromorpha triloba (Rudolphi, 1819)}

This species was found in the small intestine of cormorants from seven localities, both in South Bohemia and South Moravia. South Bohemia: pond Staré Jezero near Třeboň (November 1987: 2/2, 2-16 [9]) and pond Ženich near Třebon̆ (August 1989: 1/2, 1 [1]; July 1990: 1/6, 1); May 1991: 1/9, 3; May 1992: 1/1, 4). South Moravia: pond Starý near Pohořelice (September 1989: 1/2, 22), pond Prostřední near Lednice (September 1989: 1/6, 1), Pohořelice (July 1991: 3/6, 1-50 [19]), Jaroslavice (July 1991: 6/9, 1-70 [17]) and Nové Mlýny water reservoir (April 1992: 64\% [9/14], 1-62 [15]; May 1992: 1/6, 3). 


\section{Metorchis xanthosomus (Creplin, 1846)}

Specimens of this species were found in the gall-bladder of cormorants from both South Bohemian and South Moravian localities. South Bohemia: pond Nový Vdovec near Třeboň (July 1990: 1/2, 1) and pond Ženich near Třeboň (July 1990: 1/6, 2). South Moravia: Pohořelice (July 1991: 2/6, 2 [2]), Jaroslavice (July 1991: 2/9, 1-4 [3]) and Nové Mlýny water reservoir (April 1992: 14\% [2/14], 2-9 [6]).

Remarks. In their recently published paper, Sitko et al. (2016) consider the congeneric trematodes parasitising the gall-bladder of $P$. carbo in Central Europe to be M. bilis (Braun, 1790). However, since the morphological features used to distinguish between $M$. bilis and M. xanthosomus are not clear-cut and no specimens of the present material were studied by molecular methods, we retain the previously reported identification of this material.

\section{Paryphostomum radiatum (Dujardin, 1845)}

This species was found to be a common intestinal parasite of cormorants in both South Bohemian and South Moravian localities. South Bohemia: pond Staré Jezero near Třeboň (November 1987: 2/2, 2-8 [5]), pond Nový Vdovec (July 1990: 1/2, 2) and pond Ženich near Třeboň (August 1989: 1/2, 8; August 1990: 1/3, 1). South Moravia: pond Starý near Pohořelice (September 1989: 2/2, 25-55 [40]), pond Prostřední near Lednice (6/6, 1-210 [49]), Pohořelice (July 1991: 2/6, 2-12 [7]), Jaroslavice (July 1991: 7/9, 1-85 [25]) and Nové Mlýny water reservoir (April 1992: 50\% [7/14], 1-113 [55]; May 1992: 1/6, 1).

\section{Petasiger exaeretus Dietz, 1909}

Specimens of this species were found in the small intestine of cormorants from both South Bohemian and Moravian localities: South Bohemia: pond Ženich near Třeboň (July 1990: 1/6, 47; May 1991: 6/9, 1-2 [1]; May 1992: 1/1, 4). South Moravia: pond Starý near Pohořelice (September 1989: 2/2, 2-3 [2]), Pohořelice (July 1991: 3/6, 1-535 [180]), Jaroslavice (July 1991: 1/9, 1) and Nové Mlýny water reservoir (April 1992: 43\% [6/14], $1-14[5])$.

\section{Petasiger phalacrocoracis (Yamaguti, 1939)}

This species was commonly found in the small intestine of cormorants from both South Bohemian and South Moravian localities. South Bohemia: pond Staré jezero near Třeboň (November 1987: 2/2, 31-112 [72]) and pond Ženich near Třeboň (August 1989: 1/2, 162; July 1990: 1/6, 1; July 1990: August 1990: 1/3, 86). South Moravia: pond Starý near Pohořelice (September 1989: 2/2, 11-123 [67]), pond Prostřední near Lednice (September 1989: 3/6, 2-21 [9]), Pohořelice (July 1991: 4/6, 22-817 [358]), Jaroslavice (July 1991: 9/9, 45-1670 [291]) and Nové Mlýny water reservoir (April 1991: 8\% [1/13], 8; April 1992: 86\% [12/14], 63-1816 [484]; May 1992: 3/6, 4-9 [7]).

\section{Cestoda}

Ligula intestinalis (Linnaeus, 1758)

This cestode species was found only once in the small intestine of a cormorant from the pond Starý near Pohořelice (September 1989: 1/2, 3), South Moravia.

Ligula intestinalis is widely distributed in Europe, Asia, Africa and North America (Dubinina 1980). Its definitive hosts are various fish-eating birds, such as gulls, grebes, herons, cormorants and others. In the Czech Republic, adults of this cestode were recorded from Larus ridibundus Linnaeus, Podiceps cristatus Linnaeus, P. nigricollis Brehm, P. ruficollis (Pallas) and Sterna hirundo Linnaeus (see Sommer 1954, Ryšavý 1957, Škarda 1964, Bušta et al. 1985, Ryšavý and Sitko 1992). This is the first record of L. intestinalis from P. carbo in this country, but it was reported from this host species in nearby Poland (Kanarek and Zaleśny 2014).

The first intermediate host of $L$. intestinalis is various species of copepods, in which the procercoid phase of development takes place (Dubinina 1980). The second intermediate host is various species of fishes in the abdominal cavity of which plerocercoids develop within approximately one year (Dubinina 1987). According to Moravec (2001a), 15 fish species, mainly cyprinids, were recorded as hosts of plerocercoids of $L$. intestinalis in the Czech Republic, but molecular data indicate that there are at least two morphologically indistinguishable species previously assigned to L. intestinalis (see Bouzid et al. 2008, Štefka et al. 2009).

\section{Paradilepis scolecina (Rudolphi, 1819)}

This species was found to be one of the most frequent helminth parasites in cormorants from both South Bohemian and South Moravian localites. South Bohemia: pond Staré Jezero near Třeboň (November 1987: 2/2, 593-780 [687]), pond Ženich near Třeboň (August 1989: 2/2, 13-30 [22]; June 1990: 17\% [2/12], 6-12 [9]; July 1990: 6/6, 3-107 [39]; August 1990: 2/3, 4-43 [24]; May 1991: 5/9, 1-8 [3]) and pond Nový Vdovec near Třeboň (May 1990: 1/9, 2; July 1990: 2/2, 104-293 [199]). South Moravia: pond Starý near Pohořelice (September 1989: 1/2, 28); pond Prostřední near Lednice (September 1989: 2/6, 110-123 [117]); Nové Mlýny water reservoir (April 1991: 1/13, 1; April 1992: 12/14, 16-858 [358]); Pohořelice (July 1991: 2/6, 19-62 [41]) and Jaroslavice (July 1991:6/9, 5-167 [65]).

Paradilepis scolecina is a cosmopolitan parasite of some fish-eating birds, mainly the great cormorant Phalacrocorax carbo and the pygmy cormorant $P$. pygmaeus (Pallas), as well as some species of Pelecanus Linnaeus; occasionally, ibises Plegadis falcinellus (Linnaeus) and falcated ducks Anas falcata Georgi become infected (Dziekońska-Rynko and Dzika 2011).

In the Czech Republic, adults of P. scolecina were previously recorded from $P$. carbo by Moravec et al. (1988) in South Bohemia, Ryšavý and Sitko (1992) in central Moravia and Straková (1999) in South Moravia, whereas 
conspecific metacestodes in fishes were reported by Scholz (1989a,b) in South Bohemia (see also Moravec 2001a) and by Scholz et al. (2004) (localities not given).

According to Jarecka (1970), the copepod Eudiaptomus graciloides (Lilljeborg) serves as a suitable experimental first intermediate host of $P$. scolecina, in the body cavity of which a larva (called cercoscolex by Jarecka 1970) develops within 20 days. The second intermediate host is various species of fishes, mainly cyprinids, but also those belonging to some other fish families (Scholz et al. 2004).

\section{Nematoda}

Baruscapillaria rudolphii Moravec, Scholz et Našincová, 1994

This capillariid was found in the small intestine of cormorants only from the Nové Mlýny water reservoir (April 1992: 14\% [2/14], 2 [2]), South Moravia.

Baruscapillaria rudolphii was described as a new species from $P$. carbo by Moravec et al. (1994) based on the above-mentioned specimens collected in South Moravia. On the basis of literature data, the authors elucidated the taxonomic status of Capillaria carbonis (Rudolphi, 1819) (=nomen nudum) and pointed out that different congeneric species were reported under this name from cormorants by previous authors. They established Baruscapillaria carbonis (Dubinin et Dubinina, 1940) as a valid name for one of these species parasitising cormorants in Europe, whose morphology is very different from that of $B$. rudolphii; they considered the specimens reported by Baruš and Sergejeva (1990) as $B$. carbonis to be possibly conspecific with B. rudolphii.

Frantová (2001) redescribed B. carbonis based on specimens collected from $P$. carbo in the Czech Republic (South Bohemia) and thus confirmed the existence of two species of Baruscapillaria Moravec, 1982 from cormorants in Central Europe. Subsequently, both these Baruscapillaria spp. were reported by Sitko and Okulewicz (2010) from cormorants in Moravia: B. carbonis from P. carbo and Phalacrocorax pygmaeus in Pohořelice (South Moravia), Tovačov and Záhlinice (both Central Moravia; it is not clear from the publication to which host species the given localities refer to) and B. rudolphii from $P$. carbo in Záhlinice. Baruscapillaria carbonis and B. rudolphii have recently been reported from cormorants in freshwater and brackish-water environments from northeastern Poland (Kanarek and Zaleśny 2014).

The life cycle of B. rudolphii (as well as that of B. carbonis) remains unknown. Two congeneric species, Baruscapillaria anseris (Madsen, 1945) and Baruscapillaria obsignata (Madsen, 1945), both parasites of birds, have a direct (homoxenous) life cycle without an intermediate host (Anderson 2000, Moravec 2001b). However, it can be expected that some paratenic hosts (aquatic oligochaetes or fishes) are involved in the cycle of B. rudolphii and are probably the source of infection for cormorants.

\section{Contracaecum rudolphii Hartwich, 1964}

Fig. 2

Specimens of this nematode were frequently found in the stomach of cormorants from both South Bohemian and South Moravian localites. South Bohemia: pond Staré Jezero near Třeboň (November 1987: 2/2, 10-17 [14]), pond Ženich near Třeboň (August 1989: 2/2, 6-11 [9]; June 1990: 42\% [5/12], 1-7 [3]; July 1990: 8/9, 1-15 [5]; August 1990: 3/3, 5-15 [9]; May 1991: 7/9, 1-3 [2]) and pond Nový Vdovec near Třeboň (May 1990: 1/9, 2; July 1990: 2/2, 10-41 [26]). South Moravia: pond Starý near Pohořelice (September 1989: 2/2, 34-37 [36]), pond Prostřední near Lednice (September 1989: 6/6, 13-27 [19]), Nové Mlýny water reservoir (April 1991: 23\% [3/13], 1 [1]; April 1992: 100\% [14/14], 1-735 [183]; May 1992: 2/6, 2-3 [3]), Pohořelice (July 1991: 5/6, 8-94 [46]) and Jaroslavice (July 1991: 9/9, 1-278 [67]).

Contracaecum rudolphii was described by Hartwich (1964) based on museum specimens from the oesophagus and stomach of cormorants P. carbo collected in Berlin, Germany in May of 1816 and misidentified by Rudolphi (1819) as Ascaris spiculigera Rudolphi, 1809 (= syn. of Contracaecum microcephalum [Rudolphi, 1809]). In former Czechoslovakia, Vojtěchovská-Mayerová (1952) and Ryšavý (1958) reported Contracaecum microcephalum and C. spiculigerum (Rudolphi, 1809), respectively, from cormorants $P$. carbo examined in Podunajské Biskupice, southern Slovakia (present Slovak Republic), but it is almost sure that the nematodes in both these cases belonged, in fact, to the later described C. rudolphii. From the territory of the present Czech Republic, C. rudolphii was, for the first time, reported by Moravec et al. (1988) from $P$. carbo in South Bohemia and later from the same host species by Baruš et al. (2000; see also Baruš et al. 2001), Frantová (2002) and Sitko and Okulewicz (2010) in South Moravia, South Bohemia and central Moravia, respectively. The last-named authors recorded C. rudolphii also from $P$. pygmaeus and an additional 13 host species belonging to other genera of birds.

The morphology of nematodes of the present material corresponds well to the original description of C. rudolphii by Hartwich (1964) based on European specimens as well as to the redescription of this species provided by $\mathrm{Li}$ et al. (2013) on the basis of LM and SEM studies of specimens from $P$. carbo sinensis in China. As can be seen in Fig. 2, important taxonomic features such as the cephalic structures (Fig. 2A-C,E), the number and distribution of male postanal papillae and phasmids (Fig. 2D,G), and the presence of an unpaired median papilla on the anterior cloacal lip (Fig. 2D,G) are typical of this species. As already pointed out by Hartwich (1964), a characteristic feature of C. rudolphii is the shape of the distal end of spicules (Fig. 2F), by which this species clearly differs from three other congeners parasitising birds in Europe, i.e. C. microcephalum, C. micropapillatum (Stossich, 1890) and C. variegatum (Rudolphi, 1809).

In addition to the Palaearctic Region, C. rudolphii, mostly from cormorants, was reported in other zoogeographical regions in Africa, Nearctic and Neotropical Americas and Australia (e.g. Hartwich 1964, Torres et al. 2000, 2005, Barson and Marshall 2004, Amato et al. 2006, Shamsi et al. 2009a,b). However, molecular studies have indicated that $C$. rudolphii is a complex of several not yet 

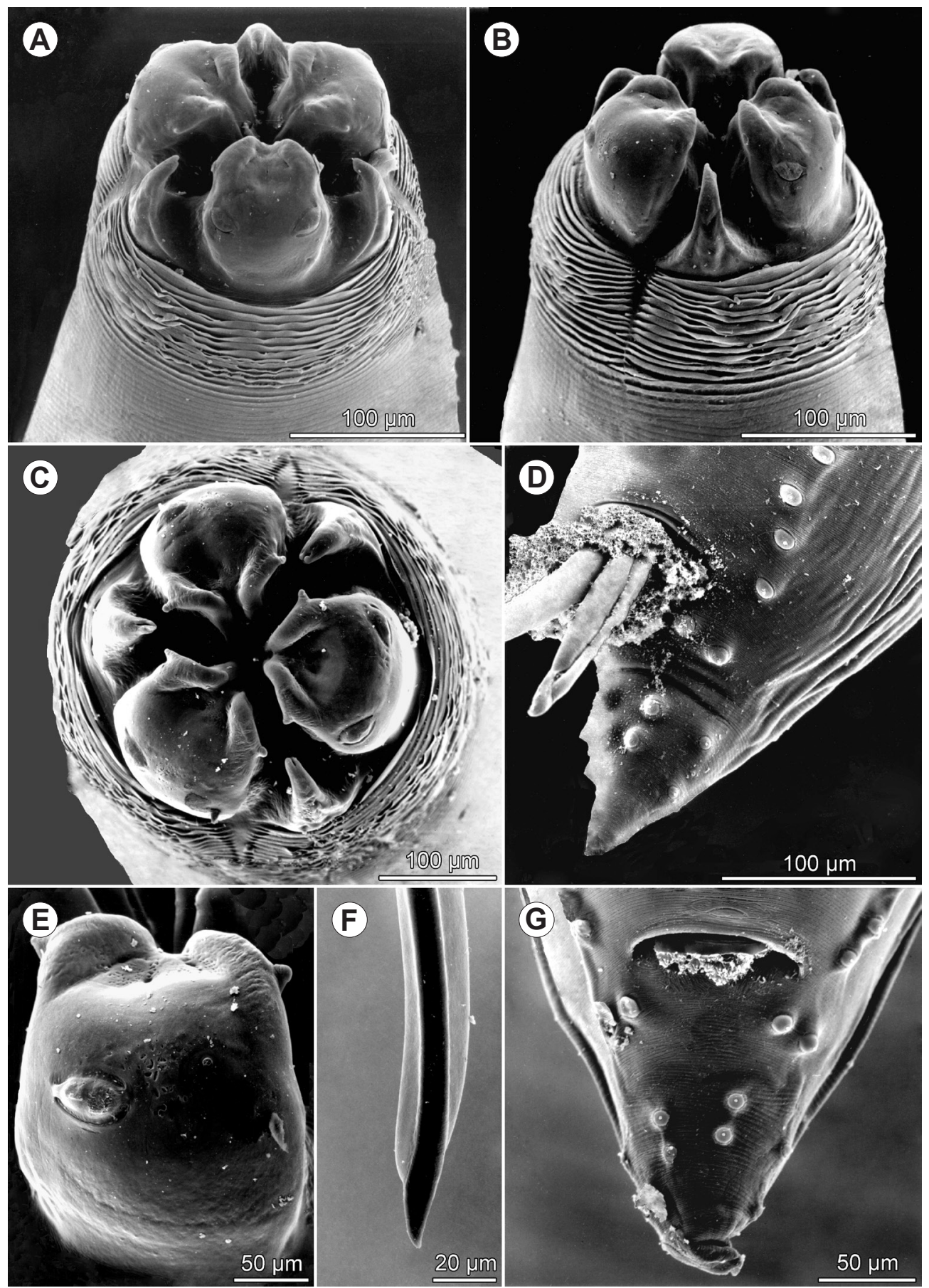

Fig. 2. Contracaecum rudolphii Hartwich, 1964 from Phalacrocorax carbo sinensis (Blumenbach), scanning electron micrographs. A-C - cephalic end, subdorsal, sublateral and apical views, respectively; D - tail of male, sublateral view; $\mathbf{E}$ - subventral lip; F - distal end of spicule, lateral view; $\mathbf{G}$ - tail of male, ventral view.

formally established sibling species, which were designated as C. rudolphii A, C. rudolphii B, C. rudolphii C, C. rudolphii D and C. rudolphii E (see Garbin et al. 2011). Of them, only C. rudolphii A and C. rudolphii B are reported from Europe.

According to Mattiucci et al. (2002), colonies of the great cormorant $P$. carbo sinensis living in freshwater environments in Central Europe are parasitised by nematodes belonging to the taxonomic unit provisionally designated as $C$. rudolphii $\mathrm{B}$; molecular support for this contention is presented by Szostakowska and Fagerholm (2007) identifying only C. rudolphii B in fishes from freshwaters in Poland. Their subsequent studies (Szostakowska and Fagerholm 2012) showed that C. rudolphii A from cormorants in Finland and Poland occurred in brackish-water regions, whereas C. rudolphii $\mathrm{B}$ in freshwater sites, although mixed infections also occurred. Some C. rudolphii specimens of the present material from cormorants in South Bohemia and South Moravia were examined by molecular methods by the research team of the Institute of Parasitology (then 

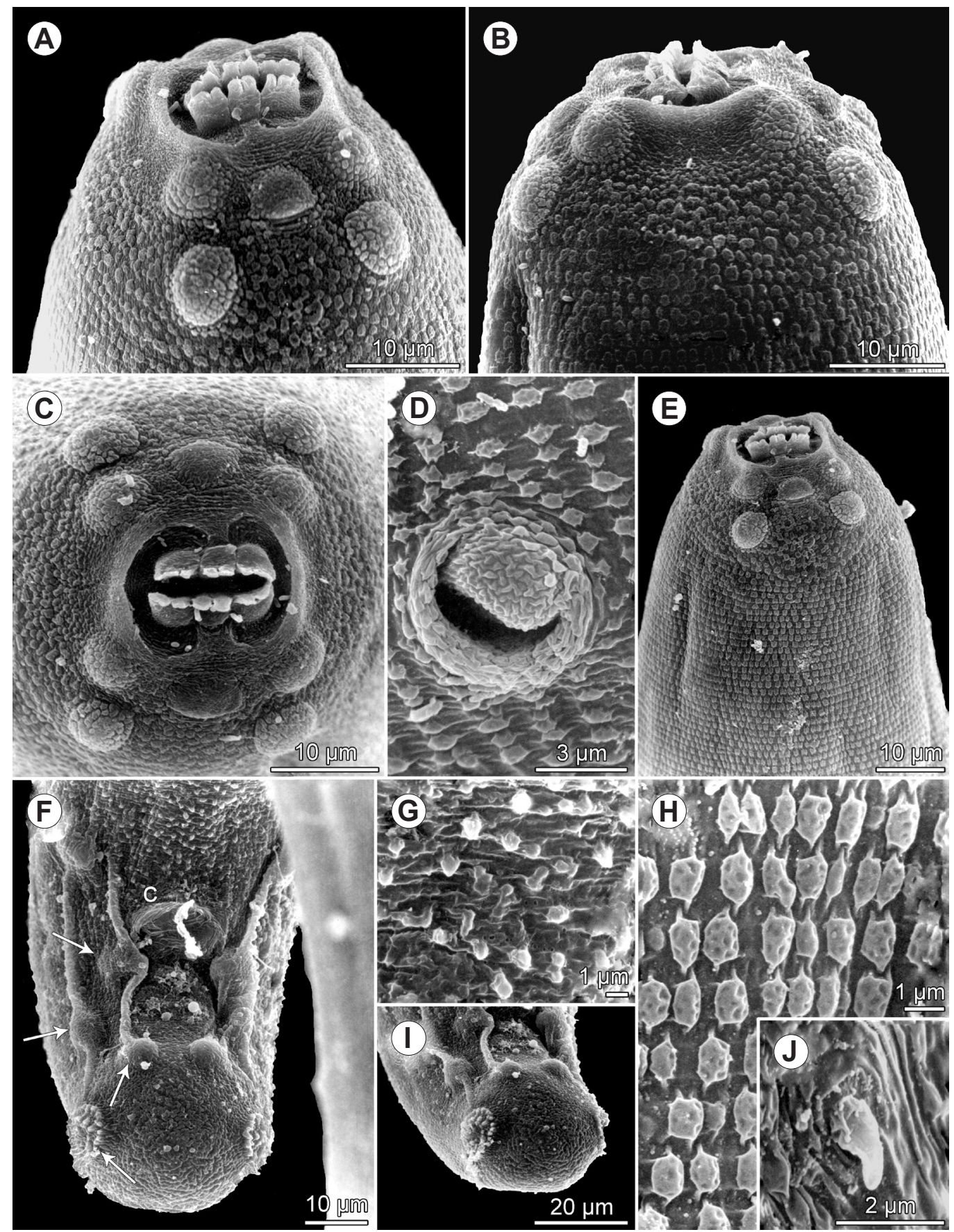

Fig. 3. Desmidocercella incognita Solonitsin, 1932 from Phalacrocorax carbo sinensis (Blumenbach), scanning electron micrographs. A-C - cephalic end, sublateral, dorsoventral and apical views, respectively; D - excretory pore; $\mathbf{E}$ - anterior end of body, lateral view; $\mathbf{F}$ - posterior end of male, ventral view (arrows indicate postanal papillae); $\mathbf{G}$ - precloacal cuticular ornamentations; $\mathbf{H}$ - cuticular ornamentations at anterior part of body; $\mathbf{I}$ - tail tip of male, apical view; $\mathbf{J}$ - deirid. Abbreviation: c - cloacal aperture.

headed by Lia Paggi), Università degli Studi di Roma 'La Sapienza', Italy, who confirmed their belonging to C. rudolphii B (see Moravec 2009).

Adults of $C$. rudolphii are parasites mainly of cormorants, less often of some other piscivorous birds (e.g. Hartwich 1964). In Europe, the life cycle of this nematode (reported as C. spiculigerum) was experimentally studied by Mozgovoy et al. $(1965,1968)$ and, subsequently, as C. rudolphii, by Dziekońska-Rynko and Rokicki (2007, 2008) and Moravec (2009). The available data show that the nematode third-stage larvae develop inside eggs in the external environment (water) and are already infective for young cormorants. However, a variety of invertebrate (copepods, larvae of aquatic insects) and fish paratenic hosts usually participate in the transmission of C. rudolphii to the definitive host, a piscivorous bird (Moravec 2009). Consequently, infected fishes are by far the main source of infection of cormorants with C. rudolphii. Cyprinus carpio Linnaeus and Tinca tinca (Linnaeus) from the pond Ženich in April and May of 1991 and Rutilus rutilus (Linnaeus) from the Nové Mlýny water reservoir in August of 1992, were recorded as natural paratenic hosts of $C$. rudolphii 
third-stage larvae (F.M. - unpubl. data). The larvae were found encapsulated on the host's gut surface and their morphology was identical with that of larvae from experimental infections (Moravec 2009).

\section{Desmidocercella incognita Solonitsin, 1932}

Fig. 3

This nematode species was commonly found in the air sacs and lungs of cormorants from both South Bohemian and South Moravian localities. South Bohemia: pond Staré Jezero near Třeboň (November 1987: 1/2, 18) and pond Ženich near Třeboň (August 1989: 1/2, 4; July 1990: 2/6, 2-7 [5]; August 1990: 2/3, 1-4 [3]; May 1991: 8/9, 4-218 [60]). South Moravia: Pohořelice (July 1991: 3/6, 1-12 [5]), Jaroslavice (July 1991: 4/9, 4-23 [15] and Nové Mlýny water reservoir (April 1992: 29\% [4/14], 2-19 [7]).

According to Skryabin et al. (1967) and Baruš et al. (1978), D. incognita is widely distributed over Europe and Palaearctic Asia. Moravec et al. (1988) were the first to record this nematode species from cormorants $P$. carbo in the Czech Republic (South Bohemia) and they provided its description based on LM examination of available specimens. Later Sitko and Okulewicz (2010) reported D. incognita from P. carbo in Záhlinice, central Moravia, Czech Republic. Kanarek and Zaleśny (2014) found it from the same host species in northern Poland.

The original description of Desmidocercella incognita (syn. D. skrjabini Gushanskaya, 1950) by Solonitsin (1932; see also Skryabin et al. 1967) was inadequate. A more detailed description of this species (reported as D. skrjabini) was provided by Gushanskaya (1950), which subsequently was taken over by Skryabin et al. (1967) and Baruš et al. (1978).

Remarks. Skryabin et al. (1967) and Baruš et al. (1978) cited the authority of Desmidocercella skrjabini as Gushanskaya, 1949. However, this species is only listed and illustrated, but not described in the Key to Parasitic Nematodes by Skryabin et al. (1949). Therefore, in accordance with the International Code of Zoological Nomenclature, this species name is invalid. Because the first description of this species was published by Gushanskaya (1950), the usable name is D. skrjabini Gushanskaya, 1950.

Later, as mentioned above, Moravec et al. (1988) redescribed D. incognita from $P$. carbo in former Czechoslovakia. However, some features in these nematodes, especially cephalic structures, are difficult to observe under the LM. Within the present study, some adult specimens of $D$. incognita were, for the first time in this species, studied by SEM and some new, taxonomically important but previously unreported features were revealed.

Solonitsin (1932) and Moravec et al. (1988) reported the nematode body of this species to be transversely striated, but, in fact, the surface of entire body is densely covered with transverse rows of minute papilla-like elevations; similar elevations also cover cephalic papillae and amphids (Fig. 3A-J). These cuticular structures are somewhat modified (more or less spike-like) in the ventral precloacal region of males (Fig. 3F,G).

The cephalic end of $D$. incognita was previously described as bearing "two lateral lips and eight cephalic pa- pillae" (Solonitsin 1932, Gushanskaya 1950), but it was never studied in apical view. The present SEM study shows that the oral aperture is oval, partly covered by two lateral pseudolabia and surrounded by eight large submedian cephalic papillae arranged in two circles (each consisting of four papillae) and a pair of large dome-shaped amphids located at the level of inner cephalic papillae (Fig. 3A-C,E). In apical view, the basal part of each pseudolabium is narrow, growing up from the lateral wall of the buccal cavity, but the distal portion of pseudolabium is markedly distended dorsally and ventrally. The outer rim of the distended pseudolabial portion bears a row of five forwardly directed teeth, arranged in three groups (two teeth in median group and three teeth in each dorsal or ventral group) (Fig. 3A-C,E).

For the first time, the presence of small lateral deirids located approximately at the level of the nerve ring (Fig. 3J) and the structure of the excretory pore (Fig. 3D) were observed. The presence of seven pairs (three preanals and four postanals) of caudal papillae in the male, as described by Gushanskaya (1950) and Moravec et al. (1988), was confirmed; unlike other caudal papillae, the papillae of the last postanal pair are covered by numerous denticles (Fig. 3F,I).

The life cycle of $D$. incognita is unknown, as those of other congeneric species. Larvae of the related species Desmidocercella numidica (Seurat, 1920) from the eyes of naturally infected fishes were experimentally fed to herons, Ardea cinerea Linnaeus, by Dubinin (1949) who obtained adult parasites. Fishes probably serve as paratenic hosts of this nematode, whereas the intermediate hosts are likely to be aquatic invertebrates (Moravec 2013). It can be assumed that $D$. incognita also utilises fishes as paratenic hosts, which become the main source of infection for cormorants.

Syncuaria squamata (von Linstow, 1883) Figs. 4, 5

Specimens of this nematode were found in the stomach of cormorants from both South Bohemian and South Moravian localities. South Bohemia: pond Ženich near Třeboň (August 1989: 1/2, 3; July 1990: 1/6, 8; August 1990: 2/3, 1-2 [2]; May 1991: 3/9, 1-12 [5]). South Moravia: pond Starý near Pohořelice (September 1989: 1/2, 1), Pohořelice (July 1991: 4/6, 1-4 [3]), Jaroslavice (July 1991: 3/9, 2-4 [3]) and Nové Mlýny water reservoir (April 1992: $21 \%$ [3/14], 1-3 [2]).

According to Wong et al. (1986), S. squamata is a specific parasite of different species of cormorants. It was originally described by von Linstow (1883) as Filaria squamata solely from females found in $P$. carbo from Central Asia, but conspecific males were reported only by Saidov (1954), who had provided a more complete species description. Now this nematode is known as a parasite of cormorants in Europe, Palaearctic (Central Asia, Transcaucasia) and South-East Asia and is also reported from North, Central and South Americas (Baruš et al. 1978, Wong et al. 1986, Moravec 1990, Fedynich et al. 1997, Monteiro et al. 2006). Kanarek and Rolbiecki (2006a) recorded S. squamata from $P$. carbo sinensis in northern Poland. 

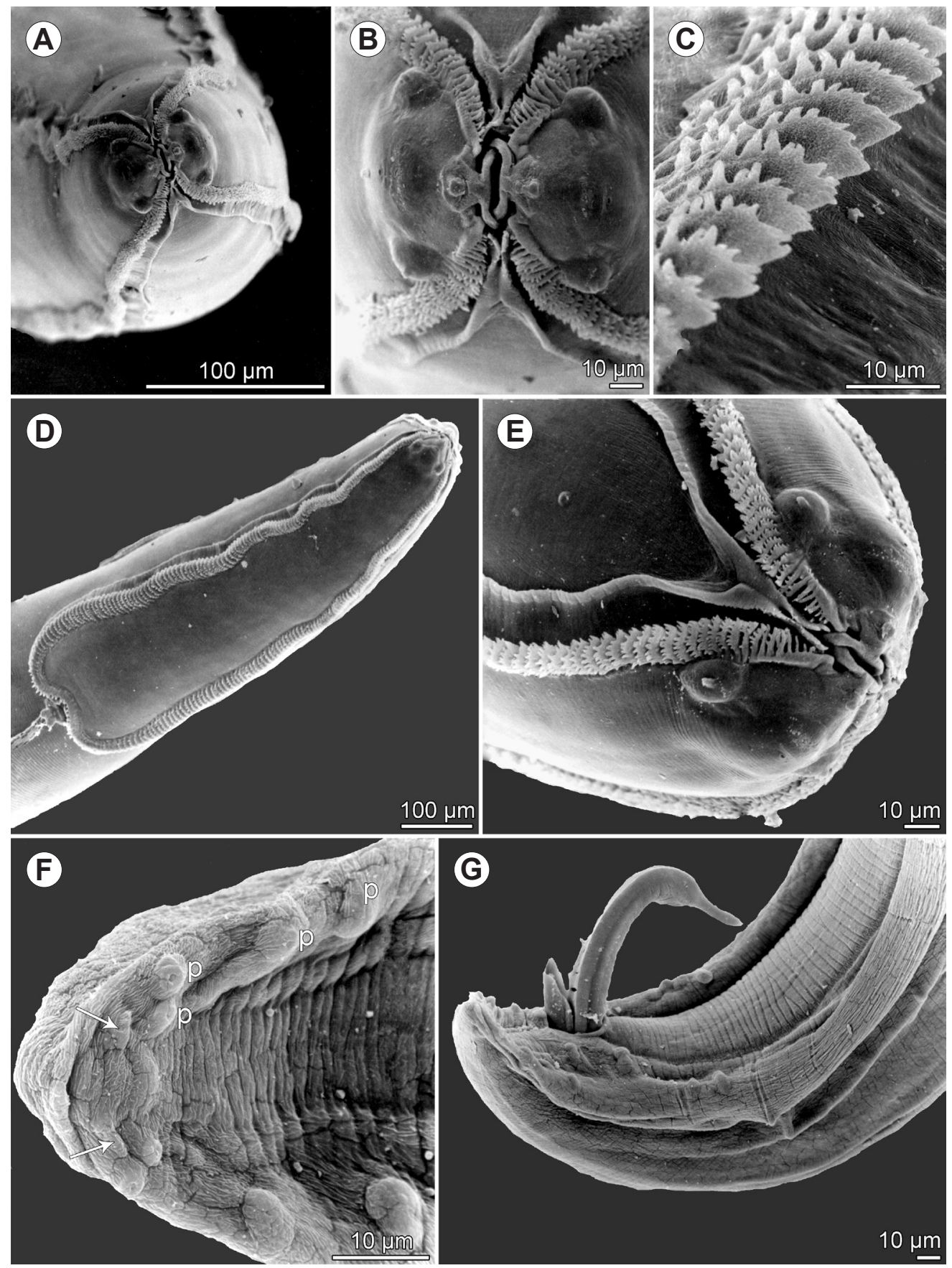

Fig. 4. Syncuaria squamata (von Linstow, 1883) from Phalacrocorax carbo sinensis (Blumenbach), scanning electron micrographs. A - cephalic end, apical view; B - same, larger magnification; C - detail structure of cuticular cordon; D - anterior end of body, lateral view; $\mathbf{E}$ - cephalic end, lateral view; $\mathbf{F}$ - tail of male, ventral view (arrows indicate phasmids); $\mathbf{G}$ - posterior end of male, lateral view. Abbreviation: $\mathrm{p}$ - postanal papilla.

Based on LM examinations, specimens of S. squamata of the present material from $P$. carbo in the Czech Republic were already described by Moravec (1990). Except for two SEM micrographs of the anterior end of adult S. squamata from Phalacrocorax auritus auritus (Lesson) in Canada published by Wong and Anderson (1987), this species was not previously studied by SEM. Consequently, the present study is the first one providing results of the SEM examination of $S$. squamata from its type host species, $P$. carbo. This study made it possible, among others, to study in detail the cephalic structures which have never been properly described, as well as to recognise the actual caudal structures in the male.

Wong et al. (1986) illustrated the cephalic end of $S$. squamata in apical view, but it is very different from that visible on the SEM micrograph (fig. 20 in their paper) based on the same material and published by Wong and Anderson (1987). It is apparent from Fig. 4A,B,E of the present study (as also from fig. 20 of Wong and Anderson 1987) that, in apical view, the oral aperture is dorsoventrally elongate, slit-like, surrounded by two lateral pseudolabia and two (one dorsal and one ventral) inter- 

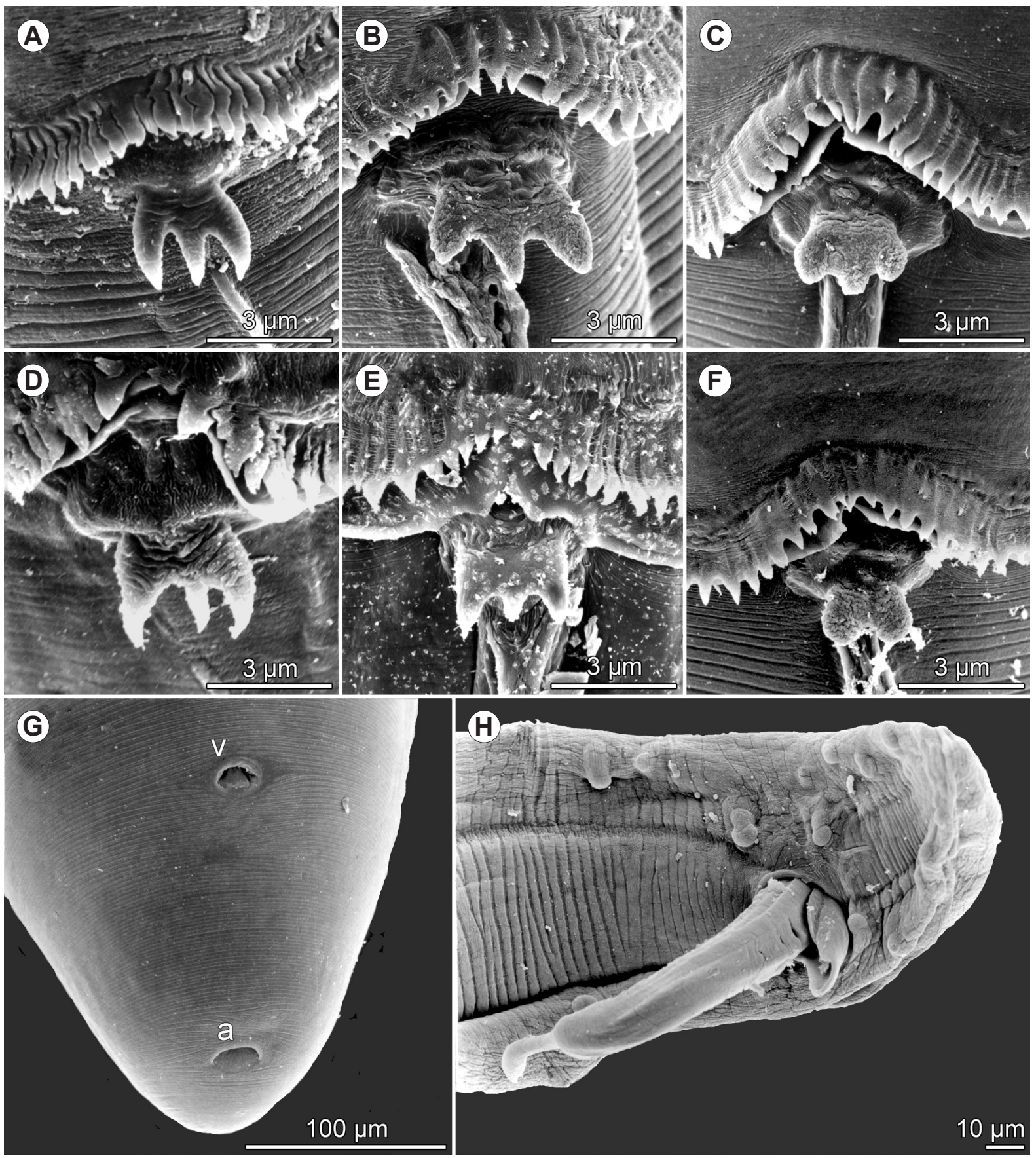

Fig. 5. Syncuaria squamata (Linstow, 1883) from Phalacrocorax carbo sinensis (Blumenbach), scanning electron micrographs. A-F - shape variations of deirids in different specimens; $\mathbf{G}$ - posterior end of female body, ventral view; $\mathbf{H}$ - posterior end of male, ventral view. Abbreviations: a - anus; v - vulva.

labia with bifid proximal ends. The proximal end of each pseudolabium forms a small narrowed, somewhat convergent portion with a very thin and rather long dorsal and a ventral extensions. The region of this pseudolabial narrowed portion is slightly raised and there is a large rounded elevation at its base. Each pseudolabium bears a pair of large submedian cephalic papillae and a lateral amphid at its base (Fig. 4A,B,D,E). Each interlabium divides posteriorly just posterior to the level of cephalic papillae and each of its two arms is continuous with the outer cuticular fold extending posteriorly along the cordon consisting of wide serrated crescent-shaped cuticular plates (Fig. 4A-E); the folds as well as cordons begin at the dorsal and ventral sides, continue posteriorly and anastomose on lateral sides (Figs. 4D, 5A-F).

Although Wong et al. (1986) described and illustrated deirids of S. squamata as to be bifurcate, Kurochkin (1958) observed a considerable variability in the shape of deirids in specimens of $S$. squamata from $P$. carbo in the Astrakhan Nature Reserve, Russia, because deirids with two, three or even more posteriorly oriented conical teeth were present. The same was found in specimens of the present material, where bifurcate and trident deirids occurred (Fig. 5A-F). Bifid and trifid deirids were also found in specimens of 
S. squamata from Phalacrocorax brasilianus (Gmelin) in Brazil (Monteiro et al. 2006).

The SEM examination of $S$. squamata confirmed the presence of ten pairs of caudal papillae (four preanal and six postanal) in the male (Figs. 4F,G, 5H), of which nine pairs are formed by pedunculate papillae and one, located more ventrally at the level of the last pair of pedunculate papillae, is represented by small sessile papillae, being followed by a pair of minute phasmids (Fig. 4F). Pedunculate papillae of the last preanal pair and those of the first postanal pair are shifted more ventrally, thus surrounding the cloacal aperture. A small median cuticular protuberance is present between ventral sessile papillae and phasmids (Fig. 4F). No ventral precloacal cuticular ornamentations (area rugosa) are present.

Figs. 4G and 5H confirm that the distal end of the left spicule in $S$. squamata is considerably narrowed, as previously described by Moravec (1990).

The life cycle of $S$. squamata was experimentally studied by Kurochkin (1958), Wong and Anderson (1987) and Moravec and Scholz (1994). Different species of ostracods (Ostracoda) serve as the intermediate hosts, in which the nematode infective third-stage larva develops. Many fish species were found to serve as suitable experimental or as natural paratenic hosts, which acquire the infection by feeding on infected ostracods (Wong and Anderson 1987, Moravec and Scholz 1994). Cormorants may be infected by swallowing intermediate hosts (ostracods) along with other food, but mainly by feeding on paratenic hosts (fishes) harbouring encapsulated nematode infective larvae. The prepatent period is about one month.

\section{Acanthocephala}

The acanthocephalans found in cormorants from South Bohemia and South Moravia have already been dealt with in more detail by Scholz et al. (1992).

\section{Andracantha phalacrocoracis (Yamaguti, 1939)}

This acanthocephalan species was recorded only once from the large intestine of a cormorant in the Nové Mlýny water reservoir (April 1992: 7\% [1/14], 7), South Moravia.

\section{Southwellina hispida (Van Cleave, 1925)}

Specimens of this species were found only once in the posterior part of the small intestine of a cormorant from the Nové Mlýny water reservoir (April 1992: 7\% [1/14], 42), South Moravia.

\section{Host category and specificity of helminth parasites of $\boldsymbol{P}$. carbo sinensis recorded in the present study}

Since all helminth species recorded from cormorants were mature and producing eggs, and because no postcyclic parasitism may occur in them, the cormorants should be considered as definitive hosts (as defined by Odening 1976) for all of them.

Regarding host specificity, the parasites recorded can be roughly divided into the following groups:

Group 1. Strictly specific-species for which cormorants (Phalacrocorax spp.) serve as the only definitive hosts: the trematodes Holostephanus dubinini, Paryphostomum radiatum, Petasiger exaeretus and $P$. phalacrocoracis, the nematodes Baruscapillaria rudolphii and Syncuaria squamata, and the acanthocephalan Andracantha phalacrocoracis.

Group 2. Species parasitising mainly cormorants, but may occasionally occur in water birds belonging to other families: the trematode Hysteromorpha triloba, the cestode Paradilepis scolecina and the nematode Contracaecum rudolphii.

Group 3. Non-specific species parasitising mostly aquatic birds of different families or even mammals: the trematodes Apophallus muehlingi, Ascocotyle longa, Cercarioides aharonii, Galactosomum lacteum, Heterophyes aequalis and Metorchis xanthosomus, the cestode Ligula intestinalis, the nematode Desmidocercella incognita, and the acanthocephalan Southwellina hispida.

However, it should be remarked that not all data in the literature seem to be reliable and may include species misidentifications. Therefore, the above helminth groups should be considered as provisional.

Nevertheless, it is apparent that the majority (47\%) of helminths recorded is represented by non-specific species (group 3; nine species), whereas a lower proportion (37\%) is formed by species specific for cormorants (group 1; seven species). As to the helminth species placed in group 2 (three species), it may well be that they are, in fact, also host specific for cormorants. According to Sudarikov (1960), H. triloba appears to be an obligate parasite of cormorants and, therefore, its frequent records from birds belonging to other families make doubts. The same concerns C. rudolphii and $P$. scolecina.

As visible from Table 2, the helminth species in groups 1 and 2 exhibited evidently much higher values of prevalence and the intensity of infection compared with those in group 3 (except for M. xanthosomus and D. incognita).

\section{Helminths of $\boldsymbol{P}$. carbo sinensis in South Bohemian and South Moravian localities}

As visible in Table 2, there is a distinct difference between the number of helminth species from cormorants in South Bohemian localities and that in South Moravian localities. Of a total number (19) of species recorded from both regions, 9 (47\%) were found in South Bohemia and $19(100 \%)$ in South Moravia.

Of interest is the proportion of specific and non-specific parasites in both regions. Whereas specific or nearly specific (groups 1 and 2) parasites of cormorants represented $78 \%$ in South Bohemian localities, they formed only $53 \%$ of species found in South Moravia. It means that the proportion of non-specific parasites of cormorants is much higher in South Moravia. In addition to other ecological causative factors, it may be due to a rather high concentration and species diversity of water birds in the large Nové Mlýny water reservoir in South Moravia, in contrast to the South Bohemian region near Třeboň, where the environment for cormorants is just formed by numerous fishponds.

In both regions under study, the examinations of cormorants were carried out in different months of the year 
(Table 1), but because only small numbers of birds were dissected, no exact data on qualitative or quantitative seasonal changes in their helminth fauna could be deduced. The same concerns observations on the composition of the helminth fauna of cormorants in their different age/size groups. Of the 13 cormorant chicks (body length 11-21 cm, weight 33-107 g) collected from nests in the Nové Mlýny water reservoir on 30 April of 1991, 7 (54\%) proved to harbour no parasites, 3 (23\%) were parasitised with C. rudolphii larvae (1 larva each), $1(8 \%)$ with $P$. scolecina (1 specimen) and 2 (15\%) with $A$. muehlingi (8 and 13 specimens). The highest number of helminth species and their highest intensities of infection were observed in 14 adult cormorants (body length 57-67 cm, weight $1.7-2.9 \mathrm{~kg}$, age about 3 years) examined from the same locality in April of 1992, in which the highest infections with the trematode $P$. phalacrocoracis (prevalence $100 \%$; intensity up to 1816 specimens), the cestode $P$. scolecina (prevalence $100 \%$; intensity up to 858 specimens) and the nematode C. rudolphii (prevalence 100\%; intensity up to 735 specimens) were recorded. The species diversity of helminths and the fact that some of them were found only during the early spring suggest that some parasites are brought into the nesting sites by cormorants coming from their winter habitats in southern countries.

Young cormorants at the age of several months $(6 \mathrm{spec}-$ imens from Pohořelice, July 1991; 9 specimens from Jaroslavice, July 1991; 6 specimens from Lednice, September 1989) were also heavily infected with parasitic worms, but the number of species was lower in comparison with that found in adult cormorants. Again, the highest intensities of infection (up to several hundreds in one cormorant) exhibited the three above-mentioned helminth species. Light infections with $C$. rudolphii and $P$. scolecina were alredy observed in cormorant chicks 1-2 weeks old (see above). The most frequent parasite of cormorants in both regions under investigation proved to be the nematode $C$. rudolphii (see Table 2).

\section{DISCUSSION}

In former Czechoslovakia, the first reports of helminth parasites of great cormorants Phalacrocorax carbo were those of Vojtěchovská-Mayerová (1952) and Ryšavý (1958). However, both of these authors examined just a few birds from the only then known Czechoslovakian nesting colony of cormorants on the Danube River (in the so called 'Cormorant Island') near the village of Biskupice, southern Slovakia (now Slovak Republic), where they recorded two species of trematodes (Paryphostomum radiatum and Hysteromorpha triloba), one cestode (Paradilepis scolecina) and one nematode (Contracaecum rudolphii [evidently misidentified as C. microcephalum or C. spiculigerum]).

From the present Czech Republic, Moravec et al. (1988) were the first to report helminths of free-living great cormorants, based on two specimens examined in the vicinity of Třeboň, South Bohemia, in which a total of six parasite species ( 3 trematodes, 1 cestode and 2 nematodes) was found. Later on, Scholz et al. (1992) reported two species of acanthocephalans and Našincová et al. (1993a) 11 spe- cies of adult trematodes from $P$. carbo in several South Bohemian and South Moravian localities. At the same time, experimental studies on the life cycles of three common parasites of cormorants, the trematode $P$. radiatum and the nematodes C. rudolphii and Syncuaria squamata, were carried out and the results were published by Našincová et al. (1993b), Moravec and Scholz (1994) and Moravec (2009). Moreover, Moravec et al. (1994) described a new capillariid species, Baruscapillaria rudolphii, from P. carbo in the Nové Mlýny water reservoir.

Based on a few P. carbo examined from the Nové Mlýny water reservoir and from ponds near Pohořelice, both South Moravia, Straková (1999) and Baruš et al. (2000) reported seven species of helminths and C. rudolphii, respectively. Subsequently, Frantová $(2001,2002)$ examined two great cormorants from the vicinity of Třebon (South Bohemia) and, in addition to C. rudolphii, she found the capillariid Baruscapillaria carbonis, not previously reported from the Czech Republic.

In the monographs (Checklists) of Sitko et al. (2006) and Sitko and Okulewicz (2010), the authors included their own, previously unpublished data on trematodes and nematodes, respectively, found in the cormorants ( $P$. carbo and $P$. pygmaeus) examined from some central and southern Moravian localities. Unfortunately, in the case of helminth species recorded from more species of hosts, the localities where such parasites were found in cormorants were not specified. Nevertheless, they reported several helminth species not previously recorded from great cormorants in the Czech Republic: the trematodes Renicola secundus Skryabin, 1924 and Tylodelphys clavata (von Nordmann, 1832) (see Sitko et al. 2006), and the nematodes Cosmocephalus obvelatus (Creplin, 1825), Cyathostoma microspiculum (Skryabin, 1915) and Eustrongylides excisus Jägerskiöld, 1909 (see Sitko and Okulewicz 2010). For the first time in the Czech Republic, they also recorded B. carbonis, B. rudolphii, $C$. rudolphii and $P$. radiatum from the pygmy cormorant $P$. pygmaeus.

It is apparent from the above text and Table 2 that, to date, the helminth fauna of great cormorants in the Czech Republic is represented by 25 species, including 13 species $(52 \%)$ of trematodes, 2 species $(8 \%)$ of cestodes, 8 species $(32 \%)$ of nematodes and 2 species $(8 \%)$ of acanthocephalans. This is comparable with recent data in the most extensive study on the helminth parasites of $P$. carbo sinensis performed by Kanarek and Zaleśny (2014) in northeastern Poland, based on examination of 491 cormorants from freshwater and brackish water localities: of a total of 31 species recorded, 30 species were found in the brackish-water habitat, whereas only 18 species in two freshwater lakes (Lake Wulpińskie and Lake Selment Wielki). As can be seen from the data by Kanarek and Zaleśny (2014) and the present study, the species composition of helminths found in the freshwater environment in Poland was very similar to that found in the Czech Republic, differing only in the presence or absence of some non-specific species.

In other European countries, only few papers dealing specifically with the helminth fauna of $P$. carbo were published (e.g. Reimer 1969, Dezfuli et al. 2002, Kanarek and 
Rokicki 2005, Kanarek and Zaleśny 2014), whereas most data on these parasites are found in broader faunistical papers or those treating individual helminth species (e.g. Kanarek and Rolbiecki 2006a,b, Dziekońska-Rynko and Dzika 2011). Many papers deal with the most important parasite of cormorants, the anisakid C. rudolphii, whose high infections, as found in the present study, were also recorded in other countries (e.g. Nottenkämper et al. 1999, Dziekońska-Rynko and Rokicki 2008, Kanarek 2011, Rokicki et al. 2011, Szostakowska and Fagerholm 2012). By the way, numerous specimens of C. rudolphii (identified by the senior author of the present paper) were collected by $\mathrm{K}$. Molnár from the stomach of $P$. carbo sinensis in Hungary on 11 March 2014 (K. Molnár, Veterinary Medical Research Institute, Budapest, Hungary - unpubl. data).

Undoubtedly, the qualitative and quantitative differences between the helminth faunas recorded from cormorants in South Bohemia and South Moravia (Table 2) are associated with different ecological conditions in these two regions. South Moravia represents the warmest region in the Czech Republic, with the more diverse fauna and flora as compared to colder South Bohemia. Moreover, whereas the water bodies in South Bohemia are represented mainly by man-made ponds with intensive fish culture, those in South Moravia include, in addition to fishponds, the large Nové Mlýny water reservoir on the Dyje (Thaya) River, which influences considerably South Moravian natural conditions. Since all helminth parasites of cormorants have complex life cycles with participation of a variety of aquatic invertebrates and vertebrates serving as intermediate or paratenic hosts, conditions in South Moravia seem to be much better for completing the helminth life cycles as compared in South Bohemia. Also other ecological factors, such as the species composition and density of local water bird populations, whose helminth communities contribute to the fauna of non-specific parasites of cormorants, should be considered.

For all helminth species recorded in cormorants, fishes serve as the important link in their life cycles (serving as paratenic or intermediate hosts); fishes harbouring the larvae of these parasites are then the source of infection for cormorants. Heavy infections with larvae of some of these species (e.g. C. rudolphii or P. scolecina) may negatively influence the health condition of infected fishes.
As experimentally demonstrated (Moravec 2009), stock carp (Cyprinus carpio), the main fish in Czech ponds, are very susceptible to infection with larvae of $C$. rudolphii. Representatives of some helminth genera recorded in cormorants (Contracaecum Railliet et Henry, 1912, Eustrongylides Jägerskiöld, 1909, Heterophyes Cobbold, 1886) are known as possible agents of serious parasitic diseases in man (Ashford and Crewe 2003).

During dissections of cormorants, the composition of their food was also recorded: this was mostly formed by small or medium-sized common carp C. carpio (body length $10-26 \mathrm{~cm})$, less often by tench Tinca tinca $(24-31 \mathrm{~cm})$ and occasionally also by silver carp Hypophthalmichthys molitrix (Valenciennes) and small white cyprinids, e.g. roach Rutilus rutilus. For example, 5 specimens of common carp (10 cm long) and 25 specimens of silver carp were found in the oesophagus and stomach of a single cormorant from the Nové Mlýny water reservoir. The finding of the tench $31 \mathrm{~cm}$ long in the stomach of another cormorant from the same locality shows that also the relatively large fishes become a prey of cormorants. This confirms that cormorants represent a big problem for fish culture, causing considerable losses in fish stocks, in particular for those in pond carp culture. In addition to direct losses caused by the consumption and mechanical damages to fish (Ondračková et al. 2012), it is necessary to take into account that cormorants are also significant distributors of agents of parasitic fish diseases, some of which might be prospectively the source of parasitoses in humans (see above).

Acknowledgements. We would like to express our gratitude to many local representatives of the then State Fishery Enterprise, branches in Třeboň and Pohořelice, for providing shot cormorants for examination, namely J. Schönbauer and Mr. Ondra. Thanks are also due to Vanda Našincová, then the reseacher of the Institute of Parasitology, Czech Academy of Sciences in České Budějovice, who made an evaluation of trematodes in the present material from cormorants and participated in bird dissections, as well as to then technicians of the same Institute, J. Borovka, I. Husáková and M. Valešová, who assisted during the laboratory examinations of cormorants; B. Škoríková helped with the preparation of illustrations and tables. This study was partly supported by the Grant Agency of the Czech Academy of Sciences (grant No. 62211), the Czech Science Foundation (grant No. P505/12/ G112) and the Institute of Parasitology, BC CAS (institutional support RVO: 60077344).

\section{REFERENCES}

Áč P. 1983: [On the occurrence of the great cormorant on the Danube]. Živa 31: 109. (In Slovak.)

Аmato J.F.R., Monteiro C.M., Аmato S.B. 2006: Contracaecum rudolphii Hartwich (Nematoda, Anisakidae) from the Neotropical cormorant, Phalacrocorax brasilianus (Gmelin) (Aves, Phalacrocoracidae), in southern Brazil. Rev. Bras. Zool. 23: $1284-1289$

Anderson R.C. 2000: Nematode Parasites of Vertebrates. Their Development and Transmission. Second Edition. CABI Publishing, Wallingford, $650 \mathrm{pp}$.

Ashford R.W., Crewe W. 2003: The Parasites of Homo sapiens. An Annotated Checklist of the Protozoa, Helminths and Arthro- pods for Which We Are Home. Second Edition. Taylor \& Francis, London and New York, $152 \mathrm{pp}$.

Barson M., Marshall B.E. 2004: First record of Contracaecum spp. (Nematoda: Anisakidae) in fish-eating birds from Zimbabwe. J. S. Afr. Vet. Ass. 75: 74-78.

Baruš V., Nagasawa K., Tenora F., Prokeš M. 2000: The head end morphology of Contracaecum rudolphii with remarks on $C$. himeu and C. umiu (Nematoda, Anisakidae). Acta Univ. Agricult. Silvicult. Mendel. Brun. 48: 69-76.

Baruš V., Sergeeva T.P., Sonin M.D., Ryzhikov K.M. 1978: Helminths of Fish-Eating Birds of the Palaearctic Region I. Nematoda. Academia, Prague, 318 pp. 
Baruš V., Sergejeva T.P. 1990: Capillariids parasitic in birds in the Palaearctic Region (3). Genus Baruscapillaria. Acta Sci. Nat. Acad. Sci. Bohemoslov. Brno 24: 1-53.

Baruš V., Tenora F., Kráčmar S., Prokeš M. 2001: Cadmium and lead concentrations in Contracaecum rudolphii (Nematoda) and its host, the cormorant Phalacrocorax carbo (Aves). Folia Parasitol. 48: 77-78.

Bouzid W., Štefka J., Hypša V., Lek S., Scholz T., Legal L., Ben Hassine O., Loot G. 2008: Geography and host specificity: two forces behind the genetic structure of the freshwater fish parasite Ligula intestinalis (Cestoda: Diphyllobothriidae). Int. J. Parasitol. 38: 1465-1479.

Bušta J., Tolkacheva L.M., Michálek J. 1985: Helminths of birds of the family Laridae in South Bohemia. Acta Soc. Zool. Bohemoslov. 49: 174-179.

Dezfuli B.S., Volponi S., Beltrami I., Poulin R. 2002: Intra- and interspecific density-dependent effects on growth in helminth parasites of the cormorant, Phalacrocorax carbo sinensis. Parasitology 124: 537-544.

Dubinin V.B. 1949: [Experimental study of the life cycles of some parasitic worms of animals in the Volga River delta.] Parazitol. Sbor., Zool. Inst. AN SSSR 11: 126-160. (In Russian.)

Dubinina M.N. 1980: Tapeworms (Cestoda, Ligulidae) of the Fauna of the USSR. Amerind Publishing Co. Pvt. Ltd., New Delhi, $320 \mathrm{pp}$.

Dubinina M.N. 1987: [Class Cestoda - Tapeworms. In: O.N. Bauer (Ed.), Key to Parasites of Freshwater Fishes of the USSR Fauna. Volume 3, Parasitic Metazoans (Part 2).] Nauka, Moscow, pp. 5-76. (In Russian.)

Dziekońska-Rynko J., Dzika E. 2011: The tapeworm Paradilepis scolecina (Rudolphi, 1819) (Cestoda: Cyclophyllidea) invasion in great cormorant [Phalacrocorax carbo sinensis (Blumenbach, 1798)] from the breeding colony in Lake Selment Wielki (northern Poland). Helminthologia 48: 23-28.

Dziekońska-Rynko J., Roкicki J. 2007: Experimental infestation of copepods and amphipods with Contracaecum rudolphii larvae. In: C.M. Nigmatullin (Ed.), Proceedings of the IV All-Russian Workshop on Theoretical and Marine Parasitology, AtlantNIRO Publishing, Kaliningrad, pp. 58-60.

Dziekońska-Rynko J., Roкicki J. 2008: Infestation of the black cormorants (Phalacrocorax carbo sinensis L. 1758 [sic]) from the colony on the Selment Wielki, with the nematode Contracaecum rudolphii Hartwich, 1964 (Nematoda, Anisakidae). Oceanol. Hydrobiol. Studies 37: 61-71.

Fedynich A.M., Pence D.B., Bergan J.F. 1997: Helminth community structure and pattern in sympatric populations of double-crested and Neotropic cormorants. J. Helminthol. Soc. Wash. 64: $176-182$.

Frantová D. 2001: Capillariid nematodes (Nematoda: Capillariidae) parasitic in the common cormorant (Phalacrocorax carbo), with redescription of Baruscapillaria carbonis (Dubinin et Dubinina, 1940). Folia Parasitol. 48: 225-230.

Frantová D. 2002: Some parasitic nematodes (Nematoda) of birds (Aves) in the Czech Republic. Acta Soc. Zool. Bohem. 66: 13-28.

Garbin L., Mattiucci S., Paoletti M., González-Acuña D., NASCETTi G. 2011: Genetic and morphological evidences for the existence of a new species of Contracaecum (Nematoda: Anisakidae) parasite of Phalacrocorax brasilianus (Gmelin) from Chile and its genetic relationships with congeners from fish-eating birds. J. Parasitol. 97: 476-492.

GushanSKAYA L.KH. 1950: [Study of Spirurata of water birds of the USSR]. Tr. GELAN 4: 55-63. (In Russian.)

HaRTwich G. 1964: Revision der vogelparasitischen Nematoden Mitteleuropas. II. Die Gattung Contracaecum Railliet \& Henry, 1912 (Ascaridoidea). Mitt. Zool. Mus. Berlin 40: 15-53.

Hudec K., ČernÝ W. (EDS.) 1972: [Fauna of Czechoslovakia, 19. Birds - Aves, Part 1]. Academia, Prague, 537 pp. (In Czech.)

JARECKA L. 1970: On the life cycles of Paradilepis scolecina (Rud., 1819) and Neogryporhynchus cheilancristrotus (Wedl, 1855)
Bauer and Bona, 1958-1960 (Cestoda-Dilepididae). Bull. Pol. Acad. Sci. 15: 159-163.

Kanarek G. 2011: Population biology of Contracaecum rudolphii sensu lato (Nematoda) in the great cormorant (Phalacrocorax carbo) from northeastern Poland. J. Parasitol. 97: 185-191.

Kanarek G., Rokicki J. 2005: The status of studies on the helminth fauna of the great cormorant (Phalacrocorax carbo sinensis) in northern Poland. Wiad. Parazytol. 51: 165.

Kanarek G., Rolbiecki L. 2006a: Syncuaria squamata (Linstow, 1883) (Nematoda: Acuariidae) in the great cormorant [Phalacrocorax carbo sinensis (Blumenbach, 1798)] in northern Poland. Helminthologia 43: 33-36.

Kanarek G., Rolbiecki L. 2006b: Third-stage larvae of Anisakis simplex (Rudolphi, 1809) in the great cormorant [Phalacrocorax carbo sinensis (Blumenbach, 1798)] from the Vistula Lagoon, Poland. Oceanol. Hydrobiol. Studies 35: 23-28.

KANAREK G., ZaLeŚNy G. 2014: Extrinsic- and intrinsic-dependent variation in component communities and patterns of aggregations in helminth parasites of great cormorant (Phalacrocorax carbo) from N.E. Poland. Parasitol. Res. 113: 837-850.

Kennedy M., Spencer H.G. 2014: Classification of the cormorants of the world. Mol. Phyl. Evol. 79: 249-257.

Kurochio Yu.V. 1958: [Study of nematodes of the genus Skrjabinocara Kuraschwili, 1941.] Tr. Astrakh. Gos. Zap. 4: 325-336. (In Russian.)

Li L., Xu Z., Zhang L.-P. 2013: Further studies on Contracaecum spasskii Mozgovoi, 1950 and C.rudolphii Hartwich, 1964 (sensu lato) (Ascaridida: Anisakidae) from piscivorous birds in China. Syst. Parasitol. 84: 225-236.

von Linstow O. 1883: Nematoden, Trematoden und Acanthocephalen gesammelt von Prof. Fedtschenko in Turkestan. Arch. Naturg. 49: 274-314.

MACHÁČEK P. 1983: [Cormorants in South Moravia]. Živa 31: 108109. (In Czech.)

Mattiucci S., Turchetto M., Bragantini F., Nascetti G. 2002: On the occurrence of the sibling species of Contracaecum rudolphii complex (Nematoda: Anisakidae) in cormorants (Phalacrocorax carbo sinensis) from Venice and Caorle lagoons: genetic markers and ecological studies. Parassitologia 44: 105.

Monteiro C.M., Аmato J.F., Амato S.B. 2006: Primeiro registro de Syncuaria squamata (Linstow) (Nematoda, Acuariidae) em biguás, Phalacrocorax brasilianus (Gmelin) (Aves, Phalacrocoracidae) no Brasil. Rev. Bras. Zool. 23: 1268-1272.

Moravec F. 1990: First record of the nematode Syncuaria squamata (Linstow, 1883) from common cormorants (Phalacrocorax carbo L.) in Czechoslovakia. Folia Parasitol. 37: 365-366.

Moravec F. 2001a: Checklist of the Metazoan Parasites of Fishes of the Czech Republic and the Slovak Republic. Academia, Prague, $168 \mathrm{pp}$.

Moravec F. 2001b: Trichinelloid Nematodes Parasitic in Cold-Blooded Vertebrates. Academia, Prague, 429 pp.

Moravec F. 2009: Experimental studies on the development of Contracaecum rudolphii (Nematoda: Anisakidae) in copepod and fish paratenic hosts. Folia Parasitol. 56: 185-193.

Moravec F. 2013: Parasitic Nematodes of Freshwater Fishes of Europe. Revised Second Edition. Academia, Prague, 601 pp.

Moravec F., Našincová V., Scholz T. 1988: New records of helminth parasites from cormorants [Phalacrocorax carbo (L.)] in Czechoslovakia. Folia Parasitol. 35: 381-383.

Moravec F., Scholz T. 1994: Observations on the development of Syncuaria squamata (Nematoda: Acuariidae), a parasite of cormorants, in the intermediate and paratenic hosts. Folia Parasitol. 41: 183-192.

Moravec F., Scholz T., Našrncová V. 1994: The systematic status of Trichosoma carbonis Rudolphi, 1819 and a description of Baruscapillaria rudolphii n. sp. (Nematoda: Capillariidae), an intestinal parasite of cormorants. Syst. Parasitol. 28: 153-158.

Mozgovoy A.A., Shakhmatova V.I., Semenova M.K. 1965: [Study of the life cycle of Contracaecum spiculigerum (Ascaridata: Anisakidae), a nematode of fish-eating birds.] Materials of 
the Scientific Conference of the All-Union Society of Helmintologists, Moscow, Pt. 4, pp. 169-174. (In Russian.)

Mozgovoy A.A., Shakhmatova V.I., Semenova M.K. 1968 [Life cycle of Contracaecum spiculigerum (Ascaridata: Anisakidae), a parasite of domestic and game birds.] Tr. GELAN 19: 129-136. (In Russian.)

Našincová V., Moravec F., Scholz T. 1993a: Trematodes of the common cormorant (Phalacrocorax carbo) in Czech Republic. Acta Soc. Zool. Bohem. 57: 31-46.

Našincová V., Scholz T., Moravec F. 1993b: The life cycle of Paryphostomum radiatum (Dujardin, 1845) (Trematoda: Echinostomatidae), a parasite of cormorants. Folia Parasitol. 40: 193-201.

Našincová V., Scholz T., Moravec F. 1994: Redescription of Petasiger exaeretus Dietz, 1909 and P. phalacrocoracis (Yamaguti, 1939) (Trematoda: Echinostomatidae), parasites of cormorants. Syst. Parasitol. 27: 139-147.

Nelson B.J. 2005: Pelicans, Cormorants and Their Relatives: Pelecanidae, Sulidae, Phalacrocoracidae, Anhingidae, Fregatidae, Phaethontidae. Oxford University Press, Oxford, pp. 162-163.

Nottenkämper D., Korbel R., Kösters J. 1999: Zum Befall von Kormoranen (Phalacrocorax carbo sinensis L., 1758 [sic]) mit Contracaecum rudolphii (Nematoda: Ascaridoidea) im Bezirk Oberbayern (D) und Kanton St. Gallen (CH). Tierärztl. Prax 27: $274-279$.

ODENING K. 1976: Conception and terminology of hosts in parasitology. Adv. Parasitol. 14: 1-93.

Ondračková M., Valová Z., Kortan J., Vojtek L., Adámek Z. 2012: Consequent effects of the great cormorant (Phalacrocorax carbo sinensis) predation on parasite infection and body condition of common carp (Cyprinus carpio). Parasitol. Res. 110: 1487-1493.

Polák M. 2010: [Birds or fish? A struggle on the river started.] Mladá fronta - Sedmička Liberec a Jablonec 2 (no. 31): 5. (In Czech.)

Reimer L. 1969: Helminthen von Kormoranen von Brutkolonien der Deutschen Demokratischen Republik. Wissensch. Z. ErnstMoritz-Arndt-Univ. Greifswald 18: 129-133.

Rokicki J., Soltysiak Z., Dziekońska-Rynko J., BorucińsKA J. 2011: Pathology associated with Contracaecum rudolphii (Nematoda: Anisakidae) infection in the great cormorant Phalacrocorax carbo (L. 1758). Helminthologia 48: 29-35.

Rudolphi C.A. 1819: Entozoorum synopsis cui accedunt mantesia duplex et indices locupletissimi. Rücker S. A., Berolini, 811 pp.

RYŠAVÝ B. 1957: [Further knowledge of the helminth fauna of birds in Czechoslovakia]. Čs. Parasitol. 4: 299-329. (In Czech with German and Russian summaries.)

RYŠAVÝ B. 1958: [The helminth fauna of cormorants (Phalacrocorax carbo L.) in Czechoslovakia]. Acta Soc. Zool. Bohemoslov. 22: 121-129. (In Czech with German and Russian summaries.)

RyšavÝ B., Siтко J. 1992: Tapeworms (Cestoda) of birds from Moravia (Czech and Slovak Federal Republic). Acta Sci. Nat. Acad. Sci. Bohemoslov. Brno 26: 1-93.

SAIDOV YU.S. 1954: [New species of parasitic worms of fish-eating birds of Dagestan.] Tr. GELAN 7: 265-274. (In Russian.)

Scholz T. 1989a: First record of the larva of Paradilepis scoleci$n a$ (Rudolphi, 1819) (Cyclophyllidea: Dilepididae) in fishes from Czechoslovakia. Folia Parasitol. 36: 65-66.

Scholz T. 1989b: Amphilinida and Cestoda, parasites of fish in Czechoslovakia. Acta Sci. Nat. Acad. Sci. Bohemoslov. Brno 23: $1-56$.

Scholz T., Bray R.A., Kuchta R., Řepová R. 2004: Larvae of gryporhynchid cestodes (Cyclophyllidea) from fish: a review. Folia Parasitol. 51: 131-152.

Scholz T., Moravec F., Našincová V. 1992: Two little-known acanthocephalans from the common cormorant, Phalacrocorax carbo, in Czechoslovakia. Acta Soc. Zool. Bohemoslov. 56 : 197-204.
Shamsi S., Norman R., Gasser R., Beveridge I. 2009a: Redescription and genetic characterization of selected Contracaecum spp. (Nematoda: Anisakidae) from various hosts in Australia. Parasitol. Res. 104: 1507-1525.

Shamsi S., Norman R., Gasser R., Beveridge I. 2009b: Genetic and morphological evidences for the existence of sibling species within Contracaecum rudolphii (Hartwich, 1964) [sic] (Nematoda: Anisakidae) in Australia. Parasitol. Res. 105: 529-538.

Sitko J., Bizos J., Sherrard-Smith E., Stanton D.W.G., Komorová P., Heneberg P. 2016: Integrative taxonomy of European parasitic flatworms of the genus Metorchis Looss, 1899 (Trematoda: Opisthorchiidae). Parasitol. Int. 65: 258-267.

Sitko J., FaltÝnková A., Scholz T. 2006: Checklist of the Trematodes (Digenea) of Birds of the Czech and Slovak Republics. Academia, Prague, $111 \mathrm{pp}$.

Sitко J., Oкulewicz A. 2010: Checklist of the Nematodes in Birds in the Czech Republic and the Slovak Republic. Comenius Mus., Přerov, 100 pp.

Skryabin K.I., Shikhobalova N.P., Sobolev A.A. 1949: [Spirurata and Filariata]. In Skryabin K.I. (Ed.), Key to Parasitic Nematodes, Vol. I. Publ. House of the USSR Acad. Sci., Moscow and Leningrad, 519 pp. (In Russian.)

Skryabin K.I., Sobolev A.A., Ivashkin V.M. 1967: [Spirurata of Animals and Man and the Diseases Caused by Them. Part 4.] Osnovy Nematodologii 16. Nauka, Moscow, 624 pp. (In Russian.)

Solonitsin I.A. 1932: Über zwei neue Arten von Nematoden in Vogel. Zbl. Bakt. Parasitenkd., Abt. I Orig., 124: 361-365.

Sommer A. 1954: [Cestodes of aquatic birds from the surroundings of Velké Meziřrićíi.] Sbor. VŠZ Brno, B, 218: 1-13. (In Czech with Russian summary.)

STRAKOvá Š. 1999: [Some new knowledge of helminths from great cormorants (Phalacrocorax carbo L.) in the region of the Nové Mlýny water reservoir (South Moravia)]. Folia Venatoria 28-29: 155-161. (In Czech with English summary.)

Sudarikov V.E. 1960: [Order Strigeidida (La Rue, 1936) Sudarikov, 1959. Part 2, superfamily Diplostomatoidea Nicoll, 1937]. In: Skryabin K.I. (Ed.), Trematodes of Animals and Man. Osnovy Trematodologii 17. Publ. House of the USSR Acad. Sci., Moscow, pp. 155-530. (In Russian.)

SzostaKowsKa B., FAgerholm H.-P. 2007: Molecular identification of two strains of third-stage larvae of Contracaecum rudolphii sensu lato (Nematoda: Anisakidae) from fishes in Poland. J. Parasitol. 93: 961-964.

Szostakowska B., Fagerholm H.-P. 2012: Coexistence and genetic variability of Contracaecum rudolphii A and Contracaecum rudolphii B (Nematoda: Anisakidae) in cormorants, Phalacrocorax carbo sinensis, in the Baltic region. J. Parasitol. 98: 472-478.

ŠKARDA J. 1964: [The helminth fauna of some free-living birds in Czechoslovakia.] Sbor. VŠZ Brno, B, 12-608: 269-293. (In Czech with English, German and Russian summaries.)

ŠTEFKA J., HYPŠA V., SCHOLZ T. 2009: Interplay of host specificity and biogeography in population structure of a cosmopolitan endoparasite: microsatellite study of Ligula intestinalis (Cestoda). Mol. Ecol. 18: 1187-1206.

Torres P., Ortega J., Schlatter R. 2005: Nematode parasites of the digestive tract in Neotropic cormorant chicks (Phalacrocorax brasilianus) from the River Cruces Ramsar site in southern Chile. Parasitol. Res. 97: 103-107.

Torres P., Valdivieso J., Schlatter R., Montefusco A., Revenga J., Marín F., Lamilla J., Ramallo G. 2000: Infection by Contracaecum rudolphii (Nematoda: Anisakidae) in the Neotropic cormorant Phalacrocorax brasilianus, and fishes from the estuary of the Valdivia river, Chile. Stud. Neotrop. Fauna Environ. 35: 101-108.

VoJTĚChOVsKÁ-Mayerová M. 1952: [New findings of parasitic worms in our birds.] Acta Soc. Zool. Bohemoslov. 16: 71-88. (In Czech with German and Russian summaries.) 
Wong P.L., Anderson R.C. 1987: Development of Syncuaria squamata (Linstow, 1883) (Nematoda: Acuarioidea) in ostracods (Ostracoda) and double-crested cormorants (Phalacrocorax auritus auritus). Can. J. Zool. 65: 2524-2531.
Wong P.L., Anderson R.C., Bartlett C.M. 1986: Revision of the genus Syncuaria Gilbert, 1927 (Nematoda: Acuarioidea). Can. J. Zool. 64: 1186-1196.

Cite this article as: Moravec F., Scholz T. 2016: Helminth parasites of the lesser great cormorant Phalacrocorax carbo sinensis from two nesting regions in the Czech Republic. Folia Parasitol. 63: 022. 